\title{
The comparative analysis of the methods for keratin extraction from sheep wool and human hair
}

\author{
V. Havryliak ${ }^{1}$, V. Mykhaliuk ${ }^{2}$ \\ vasylyna.v.m@gmail.com \\ ${ }^{1}$ Lviv Polytechnic National University, \\ Institute of Chemistry and Chemical Technology, \\ 3/4 St. Yura sq., Lviv, 79013, Ukraine \\ 2Institute of Animal Biology, \\ 38 V. Stus str., Lviv, 79034, Ukraine
}

Nowadays, biopolymers such as keratins are widely used in biomedicine due to their low toxicity, biocompatibility, and biodegradability. At the molecular level, keratins differ from other structural proteins by a high content of disulfide bonds, which provide the formation of a compact three-dimensional structure resistant to biological and chemical degradation. Native keratins are highly ordered, whereas, recovered keratins are characterized by a flexible structure with more accessible functional groups. A characteristic feature of solubilized keratins is their ability to polymerize; therefore, they are widely used to create biomaterials. The extraction of keratins from natural fibers is an important step to the development of functional biomaterials. However, this process is complicated by the presence of a large number of intramolecular and intermolecular disulfide bonds in keratins. That is why keratin extraction by breaking the intermolecular disulfide bonds while preserving the covalent bonds of the polypeptide chain is necessary. The goal of our study was to estimate the different methods of solubilized keratin obtaining. In the experiments, samples of different types of wool and human hair were used. Various methods of keratin extraction were applied. The yield of solubilized keratin (\%) was calculated from the ratio of the weight of the lyophilized keratin extract and the initial weight of fibers. The molecular mass of recovered keratins was evaluated by SDS-PAAG electrophoresis in the Laemmli buffer system. An analysis of the efficiency of keratin extraction has shown that solubilized keratin yield ranged from $32 \%$ to $51 \%$ and depended on the composition of the extraction mixture. Electrophoretic analysis of all keratin extracts obtained by various methods confirmed the presence of two bands, which according to the molecular weight corresponding to I and II types of proteins of intermediate filaments. The presence of these proteins provides self-assembly into complex structures.

Key words: keratin, extraction, sheep wool, human hair

Wool and hair are complex natural fibers with a heterogeneous morphological structure. The chemistry of the different components of keratin fibers results in their unique physical and mechanical properties. The major constituent of wool, human hair, and other animal fibers (near $90-95 \%$ by weight) is keratin. Keratin belongs to a group of insoluble proteins characterized by high sulfur content [15].

On the other hand, keratin is a biopolymer with a strongly hierarchical organization of subunits, from the a-chains, via intermediate filaments, to the fiber. At the molecular level, keratins differ from other structural proteins by a high content of cysteine, and disulfide bonds, which provide the formation of a compact three-dimensional structure resistant to biological and chemical degradation.

Nowadays, renewable biopolymers, such as keratin are widely utilized in biomedicine due to their abundant availability, low toxicity, biocompatibility, and bioactivity [5]. The structure of these proteins is similar to the extracellular matrix of biological tissues. They contain motifs such as arginine-glycine-aspartic acid and leucine-aspartic acid-valine imitating areas for cellular adhesion. For these reasons, many recent investigations of new biomaterials for clinical use have utilized keratin micromaterials as matrices for cell delivery and as scaffolds for cell-free support of native tissues [4].

It is known that extracted keratin is characterized by the ability to self-assembly and self-aggregation [17]. This feature of keratin provides its use in various fields. In the literature there are many information about the application of keratin to develop nanofibers [18], hydrogels [13], films [11], 3D-scaffold for tissue engineering [19], nanocontainers for controlled drug delivery $[6,14]$, wound healing [9], nerve regeneration [16], for the creation of functional nanomaterials [7]. 
The extraction of keratins from human hair and animal fibers is the first step towards the development of biomaterials with a high degree of functionality. However, it is important to save the natural characteristics of recovered keratin breaking only intermolecular disulfide bonds and preserving the covalent bonds of the polypeptide chain. The efficiency of keratin extraction also depends on some factors such as temperature, $\mathrm{pH}$ value, duration of extraction, choice of reducing agent, etc.

For obtaining keratin extract, there are many different methods. All of them are based on the oxidation or reduction of disulfide bonds in keratin. The obtained recovered keratin and its physicochemical characteristics significantly depend on the source and method of extraction. In this regard, the purpose of our study was to obtain soluble keratin from wool and human hair and evaluate the efficacy of keratin recovery.

\section{Materials and Methods}

In the experiments, samples of wool and human hair were used. All fibers were not chemically treated. Before the extraction of keratin, wool and hair was washed with neutral detergents, washed several times with the deionized water, and then dried at the room temperature. Surface lipids from wool and hair were extracted in the Soxhlet apparatus with tetrachloromethane for 6 hours. All fibers were cut into small pieces and then used for experiments.

\section{Extraction}

Denaturation-reduction/Urea-thiourea-mercaptoethanol method. According to this method [12], $1 \mathrm{~g}$ of fibers was put into the aqueous solution (fiber to liquid ratio 1:50) included $25 \mathrm{mM}$ Tris- $\mathrm{HCl}, 5 \mathrm{M}$ urea, $2.6 \mathrm{M}$ thiourea, and $5 \%$ 2-mercaptoethanol (2-ME), pH 8.5. The extraction was carried out for 72 hours and at a temperature of $50^{\circ} \mathrm{C}$. After filtration, the obtained solution was dialyzed in the cellulose tube (molecular weight cut off 12.000$14.000 \mathrm{kDa}$ ) against deionized water changed 3 times a day for 3 days and then centrifuged at $12,000 \mathrm{~g}$ for $20 \mathrm{~min}$. Then keratin extracts were freeze-dried.

Denaturation-reduction/Urea-thiourea-dithiothreitol method. According to this method, $1 \mathrm{~g}$ of wool or human hair was placed in the extraction mixture included $25 \mathrm{mM}$ Tris- $\mathrm{HCl}, 5 \mathrm{M}$ urea, $2.6 \mathrm{M}$ thiourea, and $5 \%$ dithiothreitol (DTT), adjusted to the $8.6 \mathrm{pH}$ with $\mathrm{HCl}$. The extraction conditions were similar to the method described above.

Sulfitolysis method. For keratin solubilization, the method Isarankura Ayutthaya et al. [1] was used. $1 \mathrm{~g}$ of fibers was treated with $50 \mathrm{ml}$ of the aqueous solution containing $8 \mathrm{M}$ urea, $0.1 \mathrm{M}$ sodium dodecyl sulfate, and $0.5 \mathrm{M}$ sodium metabisulfite (m-BS). The extraction was conducted for 72 hours and a temperature of $50^{\circ} \mathrm{C}$. Then the mixture was filtered and dialyzed. The obtained solution was lyophilized.

Analytical methods. The extraction yield of keratin (\%) was calculated from the ratio of the weight of the lyophilized keratin from extract and initial weight of the fibers.

The protein concentration in the supernatants was determined by a colorimetric Bradford method using bovine serum albumin as a standard [2]. Before electrophoresis, the samples were heated at $90^{\circ} \mathrm{C}$ for $10 \mathrm{~min}$. Electrophoresis of solubilized keratin was conducted in a $12.5 \%$
SDS-PAGE in the Laemmli buffer system [10]. Proteins in the gel were stained with $0.2 \%$ Coomassie Brilliant Blue R-250 and washed with the solution containing 7\% acetic acid. Standards Protein Molecular Weight Mass (Fermentas, Lithuania) were used to determine the molecular weight of proteins in keratin extract.

The obtained data were processed using the arithmetic mean and standard error $(\mathrm{M} \pm \mathrm{m})$ and the adequate interval for assessing the degree of probability using Student's criterion. Differences were statistically significant at $P<0.05$.

\section{Results and Discussion}

Nowadays, there are two main approaches to obtaining soluble keratin. The first is based on the dissolution of proteins by cleavage of peptide bonds to form macromolecules and mild extraction methods that provide the predominant cleavage of disulfide linkage and intermolecular hydrogen bonds. To preserve the unique properties of keratins, the second approach is usually chosen for keratin extraction. It can be realized through the oxidation or reduction of keratin. Upon keratin oxidation with peracetic acid, hydrogen peroxide, and other oxidants, disulfide groups are converted into cysteic acid residues. The obtaining derivatives called keratoses and they are impossible to restore disulfide bonds in their molecules. As a result of keratin reduction, kerateines are obtained in the form Keratin - Cys - S- and Keratin - Cys $\mathrm{SSO}_{3}{ }^{-}$. Kerateins contain amino acid residues capable of re-crossing [17]. In our experiments, we applied the method of keratin reduction using various extraction mixtures.

Table. The efficiency of keratin extraction

\begin{tabular}{l|c|c}
\hline \multirow{2}{*}{$\begin{array}{c}\text { Reducing agent } \\
\text { in the mixture }\end{array}$} & \multicolumn{2}{c}{ The extraction yield, \% } \\
\hline 2-mercaptoethanol & $31.90 \pm 1.07^{\mathrm{a}}$ & $34.16 \pm 0.17^{\mathrm{a}}$ \\
\hline Dithiothrietol & $50.65 \pm 1.46^{\mathrm{b}}$ & $40.80 \pm 2.3^{\mathrm{b}}$ \\
\hline Metabisulfite & $33.96 \pm 1.25^{\mathrm{a}}$ & $47.90 \pm 0.98^{\mathrm{c}}$ \\
\hline
\end{tabular}

Note. Results are expressed as means of 5-measurements \pm standard error. The values in a column marked with various letters differ significantly $(\mathrm{P}<0.05)$

As can be seen from the table, the efficiency of keratin extraction from wool and human hair significantly depends on the reducing agent. It should be noted that the extraction of keratin from wool was highest when the extraction mixture contained dithiothreitol. In contrast, the effect of mercaptoethanol and sodium metabisulfite on the efficiency of keratin extraction was almost identical.

Among the present reducing agents used for human hair extraction, 2-mercaptoethanol showed 34.16\% protein yield as compared to the dithiothreitol mixture $(40.8 \%)$ and m-bisulfite mixture $(47.90 \%)$.

Our data have shown that the replacement of mercaptoethanol with dithiothreitol in the extraction mixture significantly increased the efficiency of keratin extraction both from wool and human hair. However, the most effective reducing agent for keratin solubilization from human hair was metabisulfite. 

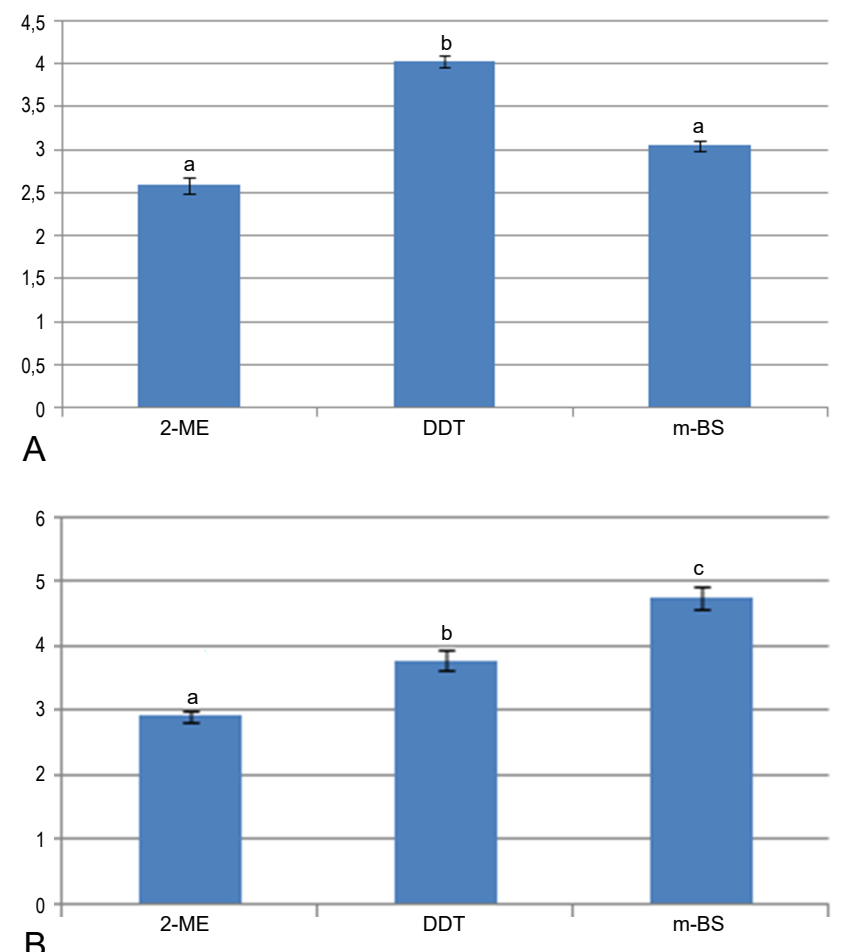

Fig. 1. Effect of reducing agent on protein concentration $(\mathrm{mg} / \mathrm{ml})$ : A - wool; B - human hair.

The value marked with various letters differ significantly $(P<0.05)$
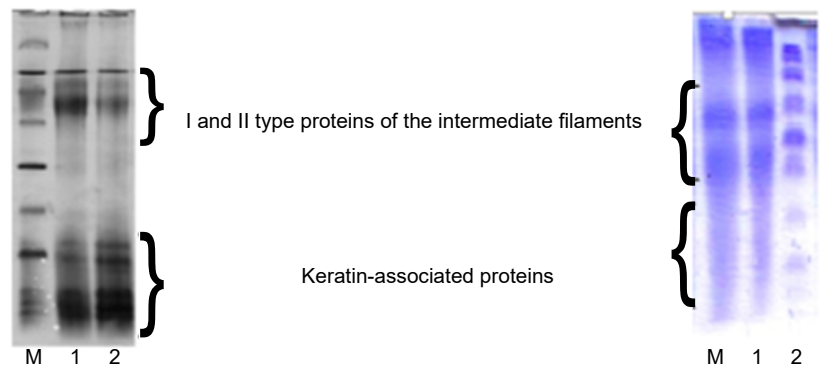

A

B

Fig. 2. SDS-PAAG of hair keratin extracts: $A$ - Lane $M-$ marker of molecular weight, lane $1-$ hair keratin extract (2-ME), lane 2 - hair keratin extract (DTT); B - hair keratin extract (m-BS)

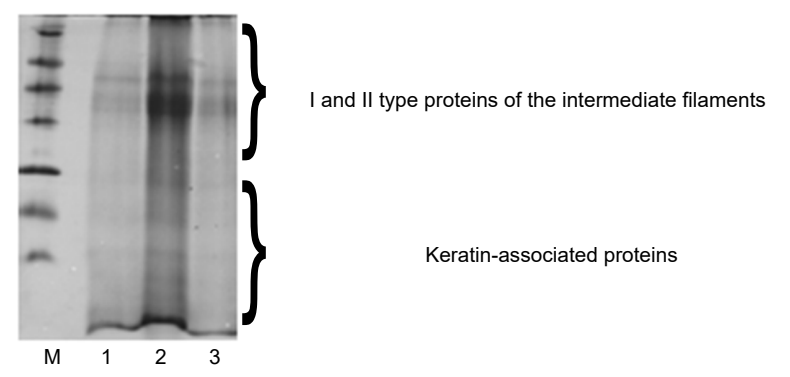

Fig. 3. SDS-PAAG of wool keratin extracts: Lane $M-$ marker of molecular weight, lane 1 - wool keratin extract (2-ME), lane $2-$ wool keratin extract (DTT); lane 3 - wool keratin extract (m-BS).
Several methods are presented in the literature source in a view of improving extraction yield. However, the results obtained by various authors are different. According to the authors [8], the extraction efficiency of keratin from feathers was $18.3 \%$ if the extraction mixture contained sodium metabisulfite, while when using $\mathrm{Na}_{2} \mathrm{~S}-86.5 \%$. In studies [17], mercaptoethanol was identified as the most effective reducing agent for feather keratin extraction.

Other authors reported about development of a new twohour protocol for the extraction of human hair shaft proteins and showed a protein recovery of $47.3 \pm 3.72 \%$ [20]. In this case, the extraction mixture contained $\mathrm{NaOH}$, sodium dodecyl sulfate, beta-mercaptoethanol, and ethylenediaminetetraacetic acid. However, some authors indicated that the optimal reducing agent for the extraction of keratin from various keratin fibers can be sodium metabisulfite, as it is cheaper and safer than mercaptoethanol and dithiothreitol [17].

The effect of the reducing agent on the protein concentration in the keratin extract is shown in fig. 1. Thus, protein concentration in the wool extract fluctuated from 2.6 to $4.02 \mathrm{mg} / \mathrm{ml}$. In human hair extracts, the protein concentration was in the range of $2.9-4.75 \mathrm{mg} / \mathrm{ml}$. As can be seen from fig. 1B, application in the extraction mixture of metabisulfite and dithiothreitol is accompanied by a significant increase in protein content in the extract of human hair $(\mathrm{P}<0.05)$.

Figures 2-3 show the electrophoretic profile of all keratin extracts. It should be noted that electrophoretic patterns of all keratin extracts obtained by methods based on the principle of denaturation-reduction do not differ significantly. Our results indicate the presence of two main bands of proteins in the range of 40-60 kDa, which, according to the literature data, belong to the proteins of intermediate filaments [3]. These proteins are characterized by low sulfur content and microfibrillar structure. They are predominantly localized in the cortex.

We also found bands of proteins with a molecular mass of $10-30 \mathrm{kDa}$, which can be considered as keratinassociated proteins that form the fiber matrix [15]. Thus, the extracted keratins via reduction and sulfitolysis ways showed the same molecular weight distribution.

\section{Conclusions}

A comparative analysis of the efficacy of different methods of wool and human hair keratin extraction has been shown that the keratin extraction yield significantly depends on the reducing agent in the extraction mixture. The use of sodium metabisulfite in the extraction mixture provides extraction of keratin from wool and hair in the range of $34-48 \%$. Electrophoretic analysis of all keratin extracts confirmed the presence of two bands, which according to the molecular weight corresponding to I and II types of proteins of intermediate filaments.

\section{Prospects for Further Research}

Hydrogels and films based on keratin biopolymer will be developed. Their structure and physicochemical parameters will be determined. Special attention will be paid to the studies of the ability of these hydrogels to combine with extracts of medicinal plants. In the future, it is planned to obtain films and hydrogels based on keratins with antimicrobial properties. 
1. Ayutthaya SIN, Tanpichai S, Wootthikanokkhan J. Keratin extracted from chicken feather waste: extraction, preparation, and structural characterization of the keratin and keratin/biopolymer films and electrospuns. J. Polymer. Environ. 2015; 23: 506-516. DOI: 10.1007/s10924-015-0725-8.

2. Bradford MM. A rapid and sensitive method for the quantitation of microgram quantities of protein utilizing the principle of protein-dye binding. Anal. Biochem. 1976; 72: 248-254. DOI: 10.1016/0003-2697(76)90527-3.

3. Cardamone JM. Investigating the microstructure of keratin extracted from wool: peptide sequence (MALDI-TOF/TOF) and protein conformation (FTIR). J. Mol. Structure. 2010; 969 (1-3): 97-105. DOI: 10.1016/j.molstruc.2010.01.048.

4. Cheng Z, Chen X, Zhai D, Gao F, Guo T, Li W, Hao Sh, Ji J, Wang B. Development of keratin nanoparticles for controlled gastric mucoadhesion and drug release. J. Nanobiotech. 2018; 16, 24 DOI: 10.1186/s12951-018-0353-2.

5. Feroz S, Muhammad N, Ranayake J, Dias G. Keratin-Based materials for biomedical applications. Bioactive Materials. 2020; 5 (3): 496-509. DOI: 10.1016/j.bioactmat.2020.04.007.

6. Foglietta F, Spagnoli GC, Muraro MG, Ballestri M, Guerrini A, Ferroni C, Aluigi A, Sotgiu G, Varchi G. Anticancer activity of paclitaxel-loaded keratin nanoparticles in two-dimensional and perfused three-dimensional breast cancer models. Int. J. Nanomed. 2018; 13: 4847-4867. DOI: 10.2147/IJN.S159942.

7. Grkovic M, Stojanovic DB, Kojovic A, Strnad S, Kreze T, Aleksic R Uskokovic PS. Keratin-polyethylene oxide bio-nanocomposites reinforced with ultrasonically functionalized grapheme. RSC Adv. 2015; 5 (111): 91280-91287. DOI: 10.1039/C5RA12402F.

8. Kamarudin NB, Sharma S, Gupta A, Kee CG, Chik SMSBT, Gupta R. Statistical investigation of extraction parameters of keratin from chicken feather using Design-Expert. 3 Biotech. 2017; 7: 127. DOI: 10.1007/s13205-017-0767-9.

9. Kim SY, Park BJ, Lee Y, Park NJ, Park KM, Hwang YS, Park KD. Human hair keratin-based hydrogels as dynamic matrices for facilitating wound healing. J. Ind. Eng. Chem. 2019; 73: 142-151. DOI: 10.1016/j.jiec.2019.01.017.

10. Laemmli UK. Cleavage of structural proteins during the assembly of the head of bacteriophage $\mathrm{T}_{4}$. Nature. 1970; 227 (1): 680-685. DOI: $10.1038 / 227680 a 0$.
11. Li R, Wang D. Preparation of regenerated wool keratin films from wool keratin-ionic liquid solutions. J. Appl. Polym. Sci. 2013; 127 (4): 2648-2653. DOI: 10.1002/app.37527.

12. Nakamura A, Arimoto M, Takeuchi K, Fujii T. A rapid extraction procedure of human hair proteins and identification of phosphorylated species. Biol. Pharm. Bull. 2002; 25 (5): 569-572. DOI: $10.1248 / \mathrm{bpb} .25 .569$.

13. Nakata R, Osumi $Y$, Miyagawa S, Tachibana A, Tanabe T. Preparation of keratin and chemically modified keratin hydrogels and their evaluation as cell substrate with drug releasing ability. J. Biosci. Bioeng. 2015; 120 (1): 111-116. DOI: 10.1016/j.jbiosc.2014.12.005.

14. Nayak KK, Gupta P. Study of the keratin-based therapeutic dermal patches for the delivery of bioactive molecules for wound treatment. Mater. Sci. Eng. C. 2017; 77: 1088-1097. DOI: 10.1016/ j.msec.2017.04.042.

15. Robbins CR. Chemical and physical behavior of human hair. Berlin Heidelberg, Springer-Verlag. 2012: 724 p. DOI: 10.1007/ 978-3-642-25611-0.

16. Sierpinski P, Garrett J, Ma J, Apel P, Klorig D, Smith T, Koman LA, Atala A, Van Dyke M. The use of keratin biomaterials derived from human hair for the promotion of rapid regeneration of peripheral nerves. Biomaterials. 2008; 29 (1):118-128. DOI: 10.1016/j.biomaterials.2007.08.023.

17. Sinkiewicz I, Śliwińska A, Staroszczyk H, Kołodziejska I. Alternative methods of preparation of soluble keratin from chicken feathers. Waste Biomass. Valor. 2017; 8: 1043-1048. DOI: 10.1007/s12649-016-9678-y.

18. Tonin C, Aluigi A, Varesano A, Vineis C. Keratin-basednanofibers. In: Nanofibers. Ed. by Kumar A. InTech. 2010; 139-158. DOI: $10.5772 / 8151$.

19. Wan X, Wang Y, Jin X, Li P, Yuan J, Shen J. Heparinized PCL/keratin mats for vascular tissue engineering scaffold with potential of catalytic nitric oxide generation. J. Biomater. Sci. Polym. 2018; 29 (14): 1785-1798. DOI: 10.1080/09205063.2018.1504192.

20. Wong SY, Lee CC, Ashrafzadeh A, Junit SM, Abrahim N, Hashim $\mathrm{OH}$. A high-yield two-hourprotocol for extraction of human hair shaft proteins. PLoS ONE. 2016; 11: 10. DOI: 10.1371/journal.pone.0164993.

\title{
Порівняльний аналіз методів екстракції кератинів 3 вовни овець та волосся людини
}

\author{
В. Гавриляк', В. Михалюк² \\ vasylyna.v.m@gmail.com \\ ${ }^{1}$ Національний університет «Львівська політехніка», \\ Інститут хімії та хімічних технологій, \\ пл. Св. Юра 3/4, м. Львів, 79013, Україна \\ ${ }^{2}$ Інститут біології тварин, \\ вул. В. Стуса, 38, м. Львів, 79034, Україна
}

На сьогодні такі біополімери, як кератини, широко застосовуються у біомедицині завдяки їхній низькій токсичності, здатності до самозбирання та біодеградації. На молекулярному рівні кератини відрізняються від інших структурних протеїнів високим вмістом дисульфідних зв'язків, що забезпечують утворення компактних тривимірних структур, стійких до хімічної та біологічної деградації. Нативні кератини мають впорядковану будову, тоді як їхня відновлена форма характеризується більш гнучкою структурою з великою кількістю доступних функціональних груп. Характерною особливістю солюбілізованих кератинів $є$ їхня здатність до полімеризації, тому їх успішно використовують для виробництва біоматеріалів. Екстракція кератинів з природних волокон є важливим кроком на шляху до створення функціональних біоматеріалів. Цей процес ускладнюється великою кількістю міжмолекулярних та внутрішньомолекулярних дисульфідних зв'язків у молекулі кератину. Тому важливо екстрагувати ці протеїни методом розриву міжмолекулярних дисульфідних зв'язків зі збереженням ковалентних зв'язків поліпептидного ланцюга. Мета наших досліджень полягала у порівнянні ефективності екстракції кератинів різними методами. В експериментах використовували вовну овець та волосся людини. Ефективність екстракції (\%) розраховували через співвідношення маси екстрагованого кератину до початкової маси волокон. Молекулярну масу відновленого кератину визначали за допомогою електрофорезу у буферній системі Леммлі. Згідно з отриманими результатами, ефективність екстракції кератинів коливалася в діапазоні від $32 \%$ до $51 \%$ і залежала від складу екстракційної суміші. Електрофоретичний аналіз усіх кератинових екстрактів показав наявність двох смуг протеїнів, що відповідають типу I і типу II протеїнів інтермедіальних фріламентів. Наявність цих протеїнів забезпечує самозбирання у складні структури.

Ключові слова: кератини, екстракція, вовна овець, волосся людини 